\title{
The Political Economy of Post-War Finland, 1945-1952
}

\section{Pihkala Erkki}

Julkaisija: Jyväskylä: Scandinavian Society for Economic and Social History and Historical Geography, 1999

Julkaisu: Scandinavian Economic History Review, vol. 47, number 3

ISSN 0358-5522

S. $26-48$

Tämä aineisto on julkaistu verkossa oikeudenhaltijoiden luvalla. Aineistoa ei saa kopioida, levittää tai saattaa muuten yleisön saataviin ilman oikeudenhaltijoiden lupaa. Aineiston verkko-osoitteeseen saa viitata vapaasti. Aineistoa saa opiskelua, opettamista ja tutkimusta varten tulostaa omaan käyttöön muutamia kappaleita.

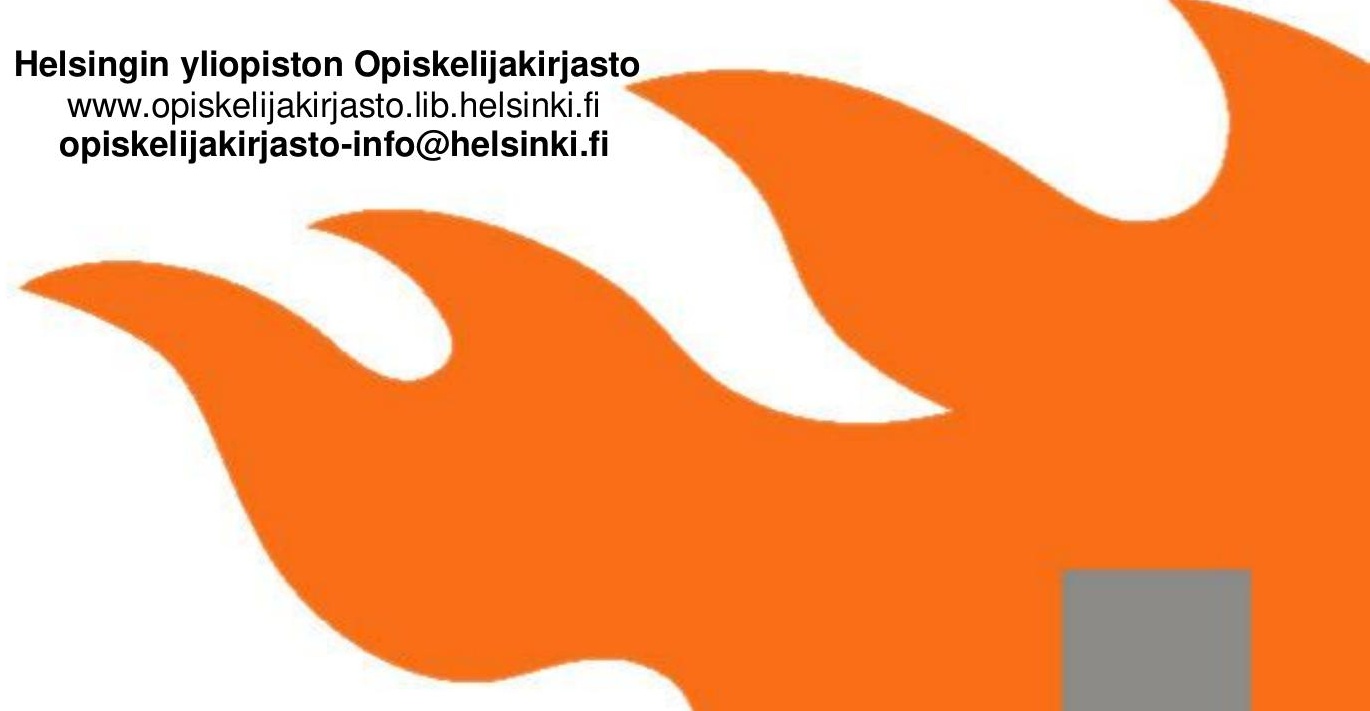




\title{
The Political Economy of Post-War Finland, 1945- 1952
}

\begin{abstract}
The paper is primarily concerned with the Finnish government's management of the Finnish economic situation after the Second World War. Overall, post-war policies were dominated by three main goals, first, how to deal with the war reparation payments required under the harsh political terms of the 1944 Armistice Treaty; secondly, to ensure the settlement of the Karelian refugees and demobilised veterans; and thirdly, the raising of production and the standard of living, including the easing of the rationing system. The focus is especially in analysing how this was financed externally and by the state economy without hyperinflation and considerable indebtedness of the state. From the point of view of the government finances, the financing of the war was transformed to the financing of the war reparations, the compensations due to the war and the settlement of the homeless people. The paper has drawn on the findings of the Studies of the Economic Growth of Finland and other sources and can be seen as a sequel to a previous article on the Finnish war economy between 1939-1945.
\end{abstract}

\section{Introduction: the peace terms}

Any peace after a total war, like the Second World War, whether won or lost, is likely to prove a complicated economic matter for an industrial society. It poses questions to do with demobilization and reconstruction, and with the ending of martial laws offers a test of democracy, while the normalization of economic institutions has to be carried on in a situation loaded with all kinds of economic and political expectations. After the Second World War for most Finns normalization meant a return to the standard of living and conditions of 1938 , but very many Finns also wanted a changed economic system. The first socialist country of the world, the Soviet Union, had emerged from the war as a second superpow-

\footnotetext{
${ }^{1}$ The paper was first presented at the XII Congress of the International Economic History Association, Session C44 (The economic history of World War II and its aftermath), Madrid, in August 1998. I am highly indebted to Professor Hugh Rockoff of Rutgers University for organizing the session, and for his (and two unknown referee's) comments and suggestions on the paper.

${ }^{2}$ Pihkala, Erkki, War consumption and Financing in Finland in the Second World War, in The Sinews of War. Essays on the Economic History of World War II, Ed. Geofrey T. Mills \& Hugh Rockoff. Ames: Iowa State UP 1993.
} 
er and many thought that its economic system - planned socialism - was the only remedy for postwar economic and social problems.

In September 1944 the Soviet Union made armistices with Rumania, Hungary and Finland. For Finland this preliminary peace treaty meant that the areas, Karelia and Salla, ceded after the Winter War in March 1940 were again surrendered. In addition, Petsamo was lost, including its newly-exploited nickel deposits as well as the outlet to the Arctic Ocean. The Hanko base was substituted for Porkkala, and leased to the Soviet Union for fifty years; it was located only twelve miles from the Finnish capital, and moreover, could be supplied by rail through Finnish territory. Furthermore, access to the Gulf of Finland, with the Estonian side being in Soviet hands, could now be barred by coastal artillery. Each of three countries, Finland, Rumania and Hungary, were obliged to pay war reparations to the Soviet Union totalling 300 million US gold dollars in 1938 prices over six years: for Finland this was equivalent to one and a half times 1938 exports.

In addition, the decisions of the Potsdam Conference of 1945 and the Peace Treaty of Paris of 1947 imposed on Finland the restitution of property removed from Karelia and East Karelia which had been occupied by the Finnish armed forces between 1941-44, and reconstruction of the property destroyed there. This also applied to the Finnish property which had been taken there after June 1941, when the new war with the Soviet Union started. German assets in Finland and Finnish debts to Germany accumulated in 1941-44 were allocated to the Soviet Union as part of the German settlement. The expenses of the Allied Control Commission and the War Reparation Commission were also to be paid by Finland, but these were minor compared to the costs of the Soviet occupation army in Hungary or Rumania.

The Finnish army of over 600,000 men and women, some 16 per cent of the total population, was to be demobilized before December 1944. The strength of the armed forces was then to be limited to 42,000 men, the Finnish navy to a maximum volume of 10,000 tons and the air force to 60 combat planes. Atomic weapons, missiles, magnetic sea mines, submarines, motor torpedo boats and bombers were forbidden, as were paramilitary organizations and civic militia. The German force in North Finland, a strong mountain army of some 200,000, was to be expelled from Finnish territory. The Soviet Army did not join in this War of Lapland against Germany, which occurred mainly in October-November 1944, although the last Germans did not leave the northwestern tip of Finland until April 1945.

The Armistice Treaty also ordered Finland to convict, as war criminals, the President of the country and seven cabinet ministers for not conducting active peace policies. They were sentenced to be jailed for some years by a Finnish special court under pressure from the Soviets, but thereafter returned to high positions. No one was executed.

Finnish compliance with the terms of the Armistice Treaty was closely monitored by the Soviet-led Allied Control Commission until its departure from Helsinki in September 1947, after the ratification of the Peace Treaty of Paris. The Paris Peace Treaty of February 1947 had confirmed the obligations of the Armistice Treaty. The transfer of German property and Finnish war-time debts to Germany then started. The signatories of the Paris Peace Treaty (the Soviet Union, the United Kingdom, the Union of South Africa, etc, but not the United States of America, which had not been involved in the war with Finland), however, did 
not require Finland to relinquish the arsenal which it had acquired as booty or had purchased during the war years. These armaments proved sufficient to equip a dozen infantry divisions, a means of self defence, although Finland's strategic position clearly left it at the mercy of the Soviet Union in the devastated and problem-ridden Europe of the immediate post-war years. ${ }^{3}$ Martial law was repealed in November 1947.

\section{The legacy of the war}

Finnish military wartime deaths numbered some 85,000 with civilian deaths at about 2,000 , in total some 2.2 per cent of the prewar population. The number of injured was about 200,000, but until 1964 only 68,000 had received compensation for their wartime traumas. The Finnish cities had not been badly damaged since the Soviet air raids had been successfully repelled and although Lapland was "'burned down" by the Germans this was of relatively small-scale importance. The physical damage caused by the war amounted to one-fiftieth of the national wealth. The costs of the war, excluding territorial losses came to some 20-33 per cent annually of the Finnish gross domestic product between 1940-44, or 27 per cent on average, military spending in 1939 and 1945 were about 10 per cent of the Finnish GDP in comparison. ${ }^{4}$ The war economy had been financed in 19401944 by restricting private expenditure to below 80 per cent of that before the war, by severally constraining investment, by running deficits on the current account, and through heavy taxation including an inflation tax. ${ }^{5}$ There was no racial genocide, and the few Finnish Jews of military age served as normal in the armed forces. At the end of the war 422,000 refugees from the ceded areas, or 12 per cent of the total population, together with the veterans, were waiting to be resettled. In addition there were 160,000 evacuees from Northern Finland, of which 56,000 had gone to Sweden. After the armistice was signed there neither was a wave of terror nor much crime, and the employment problem until 1949 proved to be a shortage of labour rather than unemployment.

Finland made the transition from war to peace with its most important institutions unchanged, that is the civil service, the courts of law, the core of the army and the police. The biggest internal political problem proved to be the increased support for communist ideas. In the elections of March 1945 the Communist-led Democratic League of the People of Finland gained 25 per cent of the seats in the Parliament and formed a coalition government with the Social Democrats and the Agrarian Party who also won a 25 per cent share each. Many of the new com-

\footnotetext{
${ }^{3}$ Nevakivi Jukka, Finnish Security Policy in a Geostrategic Perspective in Security and Insecurity; Perspectives on Finnish and Swedish Defence and Foreign Policy; Ed. Gunnar Artéus \& Jukka Nevakivi, Försvarsskolans Acta B3. Stockholm; Probus 1997, 19-24; and Vehviläinen, Olli, Finland's transition from war to peace in Bulletin of the International Committee for the History of the Second World War, N:o 27/28, 1995 (1945; Consequences and sequels of the Second World War. $18^{\text {th }}$ International Congress of Historical Sciences, Montreal 1995); 120-129.

${ }^{4}$ Nummela, Ilkka, Inter arma silent revisores rationum: Toisen maailmansodan aiheuttama taloudellinen rasitus Suomess, 1939-1952 (with English summary: The Financial Burden imposed on Finland by the Second World War during the Period 1939-1952), Studia Historica Jyväskyläensia 46. Jyväskylä 1933, $297-$ 301. The value of territorial cessions was estimated by Nummela to about ten months' worth of the GDP for 1938 . 
munist deputies had been imprisoned during the war. The years 1945-48 have thus been called 'the years of danger' because of the risk of a Communist coup d'état and /or a Soviet invasion. The Communists, however, lost ground markedly in the July 1948 elections and were then left outside the new cabinets.

In many European countries, as in Great Britain and France, the nationalisation of certain major branches of production and services (coal, steel, railways etc.) was common. In Finland there were also similar demands and a committee was set up to plan it. However, such enthusiasm was over by 1948, and in the end no branch of the economy or company was in fact nationalized. This was partly because of the continuing strict regulation of the economy. Rationing lasted in some form until the mid-1950s, and price controls until the 1980s. The improving standard of living, especially for the lower income groups, also satisfied the majority within the scope of the existing economic system. There was little that could be called 'national economic planning' if we exclude the incomes policies pursued by the government. State investment in the basic industries and the granting of import licences by the Licence Office and currency for imports by the Bank of Finland were mainly aimed at pragmatically removing production bottlenecks. On the other hand, even though the Finnish state traditionally owned some big companies, only the distribution of alcohol constituted a state monopoly, a position occurring after the abolition of prohibition in 1932.

\section{Walking the tightrope}

In 1947 Soviet-dominated governments were set up in the Eastern and Central Europe, the Cominform was formed in September, while an attempted Communist takeover took place in Greece in December leading to a civil war. In February 1948 the Communists took over in Czechoslovakia, and the Soviet Union made "friendship agreements" with the countries they had occupied. In April 1948 the Soviets threatened Berlin with a blockade, which beginning in June lasted until May 1949. NATO was not established until April 1949. In Finland in 1947 the Communists organized a series of strikes with strong pay demands from the unions and demands for the socialization of production which threatened overall economic stability. In April 1948 there were even rumours of a Communist takeover in the country.

Given this political background Finland in April 1948 considered it best to accept a Friendship, Cooperation and Mutual Assistance Pact (the FCMA pact) as demanded by the Soviet Union. The first crucial stipulation of this pact was that Finland should protect its territory against any German attack or attack from German allies, so that Finland could not be used for an attack on Soviet territory. If necessary, the pact stipulated cooperation with Soviet forces. A second stipulation, different from other friendship agreements, was that consultations should be held with the Soviet Union on whether such a threat was imminent, and what measures should then be taken. According to the latest research, the FCMA pact watered down a Communist plan to bring about a political shift to the left because of an on-going right-wing conspiracy. It also diminished the need for the Soviets to occupy Finland. ${ }^{6}$

\footnotetext{
${ }^{6}$ Rentola, Kimmo, Niin kylmää, että polttaa: Kommunistit, Kekkonen ja Kreml 1947-1958 (Burning cold: The Communists, Kekkonen and the Kremlin, 1949-1958). Helsinki: Otava 1997, 38-50.
} 
Finland's narrow room for manoeuvre dictated by the realities of foreign policy was also reflected in economic matters. On 5 June 1947 the European Recovery Program (ERP), later the Marshall Aid Plan, was announced and all the European nations were called upon to participate. The Soviet Union, however, considered the ERP to be a political offensive against it. It thus put pressure on the countries within its orbit not to accept the aid nor to join the OEEC (Organization for European Economic Cooperation) which was founded in April 1948 to coordinate the ERP.

Such a situation was very awkward for Finland, which was in need of economic aid as much as any other European country. On 8 July 1947 the Finnish Prime Minister was called to the Allied Control Commission and reminded that the Paris Peace Treaty still needed to be ratified, that war reparations could be hardened and that the 'arms cache' case referred to below was still unsettled. Soviet pressure for Finland not to participate in the ERP and not to join the OEEC can be seen as a major drawback economically for Finland. To compare the position with other countries, Norway received in Marshall aid some 255 million US dollars, and Denmark 273 million, while Austria received 678 million. Sweden received conditional aid for 107 million US dollars against grants in crowns to other European countries. In October 1947 the Soviet Union acted also to use its right of veto to prevent Finland becoming a member of the United Nations.

These incidents and developments reveal clearly enough the limited external room for manoeuvre Finland enjoyed during these "years of danger". On the other hand, the ERP promoted indirectly the expansion of Finnish exports based on its rich forest resources. Finland did not in fact join the OECD, which became the successor to OEEC in 1961, until 1969. Finland never joined COMECON, the Soviet counterpart of the OEEC.

The "arms cache" case, which became public knowledge in the autumn of 1946, was about the secret storage of weapons for 34 resistance battalions located throughout the country. Furthermore, the records, equipment and certain personnel of the Finnish military intelligence had been removed to Sweden for safekeeping. Such measures, undertaken by Finnish headquarters officers to prepare for a Soviet occupation of Finland, were a violation of the Armistice Treaty. ${ }^{7}$ There was also an apparent reluctance by the Finnish authorities in tracking down and punishing the guilty parties. The Control Commission was alarmed, suspecting an even more widely-organized underground resistance. It seems likely, however, that the effect was to make the Soviet Union more cautious in its dealings with Finland. Only much later on it was learned, for example, that in Estonia the Soviets had to work hard to repress postwar armed resistance.

In their desperate need of raw materials and other inputs needed to be imported in order to settle its war reparations, the Finns in December 1944 asked for loans from the United States, where they had a reputation as a country that paid its debts even during the Great Depression and the war years. Referring mainly to the experience after the First World War the Americans, however, let it be understood that such dollars were not to be given in order that the Soviet Union might receive its reparations. What right have the Finns or any others to suppose that it is the policy of the United States to give money to the Finnish mousetrap' was the 
answer, with Britain cautiously backing the Finns in order to obtain timber from Finland. ${ }^{8}$

During 1945, however, US opinion changed, and by the end of 1945 Finland was granted loans totalling some 40 million dollars from the Export-Import Bank for the purchase of cotton, cereals, coal and steel, trucks and machinery, but not to be used for war reparations. In January 1947 loans worth a further 30 million were again allocated. ${ }^{9}$ The interest rate was usually 3 per cent or less. Especially from the summer of 1948 the US was aiming at minimize Soviet influence in Finland by reinforcing Finland economically. Too much US economic support would have led to Soviet countermeasures, and too little would have left Finland too isolated. On the other hand, US military circles were intensively promoting full Swedish membership of NATO, which would have meant very hard times for Finland. ${ }^{10}$

In 1945 Finland received loans only from Sweden. Later on loans were also received from the United States, and from Argentina, Brazil and Colombia to buy raw materials, especially coffee. The net amount of foreign long-term loans Finland received during 1945-48 was \$ 126 million. According to its foreign trade statistics Finland paid out war reparations from September 1944 to September 1947 worth \$ 232 million. ${ }^{11}$

\section{Finnish war reparations ${ }^{12}$}

On 17 December 1944 the detailed War Reparations Programme fixed the prices of goods to be delivered at the levels of 1938 increased by 10 per cent for consumer goods and 15 per cent for capital goods, since the war reparations were to be paid only in kind. A penalty clause called for fines of 5 per cent a month for delays, with no force majeur clause. Deliveries of complex items counted only if they were 100 per cent complete. Consignments could be cancelled, if they were

\footnotetext{
${ }^{8}$ Heikkilä, Hannu, The Question of European Reparations in Allied Policy, 1943-1947, Studia Historica 27. Helsinki: Finnish Historical Society 1989, 62-63.

${ }^{9}$ Heikkilä, Hannu, Liittoutuneet ja kysymys Suomen sotakorvauksista 1943-1947 (with English summary: The Allied Countries and the Question of Finnish Reparation to the Soviet Union, 19431947), Historiallisia Tutkimuksia 121. Helsinki: Finnish Historical Society 1983, 202-208.

${ }^{10}$ The US policies are treated by Jussi M. Hanhimäki in Rinnakkaiseloa patoamassa: Yhdysvallat ja Paasikiven linja 1948-1956 (with English summary: Containing Coexistence: The United States and the Paasikivi Line, 1948-1956), Bibliotheca Historica 10. Helsinki: Finnish Historical Society 1996.

11 Oksanen, Heikki and Pihkala, Erkki, Finland's Foreign Trade, 1917-1949. Studies on Finland's Economic Growth VI, Bank of Finland Publications. Helsinki 1975, 26.

12

The problems of the Finnish war reparations have been dealt with in detail by many authors, including Charles Kindleberger, Suomen sotakorvaukset (Finnish War Reparations Revisited) in Kansantaloudellinen Aikakauskirja (The Finnish Economic Journal), vol. LXXXIII, 1987:2, 149-159; Susanna Fellman, Suomen sotakorvaukset ja metalliteollisuus (Finnish War Reparations and the Metal Industry), in Historiaa tutkimaan (Now We'll Study History), Ed. Jorma Tiainen \& Ilkka Nummela. Jyväskylä 1996 discusses the significance of war reparations for the post-war development of the metal industry.
} 
discovered to have defects after having been accepted. The level of fines rose to $\$$ 442,000 , but only $\$ 175000$ were actually paid. ${ }^{13}$

In a report drawn up in 1946 by the United States intelligence services for the Paris Peace Conference, the international burden of war reparations was estimated as follows:

\begin{tabular}{lcccc}
\hline Country & $\begin{array}{c}\text { Annual average } \\
\text { of reparations, } \\
\begin{array}{c}1948-52 \text { (million } \\
\text { US dollars) }\end{array}\end{array}$ & $\begin{array}{c}\text { Prewar GNP } \\
\text { (million } \\
\text { US dollars) }\end{array}$ & $\begin{array}{c}\text { Reparations, } \\
\text { as a per cent } \\
\text { of GNP }\end{array}$ & $\begin{array}{r}\text { Material damage, } \\
\text { as a per cent of } \\
\text { the national } \\
\text { wealth }\end{array}$ \\
\hline Bulgaria & 15 & 450 & 3.3 & 5 \\
Italy & 40 & 6000 & 0.7 & 25 \\
Rumania & 38 & 1350 & 3.0 & 10 \\
Finland & 35 & 500 & 0.7 & 22 \\
Hungary & 45 & 1050 & 4.3 & 5 \\
\hline
\end{tabular}

Source: Intelligence Research Report DCL 3773, 27 July, 1946, RG43, Box 12, National Archives (NA) by Heikkilä, Liittoutuneet ja kysymys Suomen sotakorvauksista, 191.

Only a quarter of the goods delivered as reparations consisted of Finland's traditional export items of wood and paper. The rest was made up of ships, machinery and equipment and cable products which Finland had not been exporting before the war. The Soviet Union itself had no shortage of timber, which well suited the United Kingdom which badly needed Finnish timber. The war reparations paid to the Soviet Union can be seen as a guarantee of co-operation in the future, since both the Finnish metal industry and the Finnish shipyards became dependent on future Soviet orders.

Of the deliveries actually made in 1945 , about 60 per cent consisted of wood and paper, the rest being mostly ships from the existing merchant fleet. At the close of 1945 the war reparations schedule was extended from six to eight years, which eased the delivery times for new ships and new machinery and equipment. In July 1948 the outstanding amount of reparations was halved; the nominal total to be paid was thus 226.5 million US gold dollars. Comparable reductions were also made for Rumania and Hungary. And at the end of 1948 Finland had in fact made payments amounting to 159 million 'war reparations dollars'.

There are several studies of the real value of the war reparations. One shows that Finland would have needed 445 million US dollars if it had actually bought from the United States the goods actually delivered in reparations. Another estimate put the amount at 546 million at 1952 prices, while another put it at 570 million. ${ }^{14}$ The burden of war reparations at a percentage of the Finnish GDP averaged 4.5 per cent annually between 1945-47, 3.3 per cent between 1948-49 and 1.5 per cent between 1950-52, calculated on the basis of the state expenditures on them. In terms of Finnish industrial production the corresponding percent-

14

Pihkala, Erkki, Kauppapolitiikka ja ulkomaankauppa 1945-1986, in Sotakorvauksista vapaakauppaan (Foreign Trade Policies and Foreign Trade 1945-1986, in From War Reparations to Free Trade): Kauppa- ja teollisuusministeriön satavuotisjuhlakirja, Ed. Yrjö Kaukiainen \& Erkki Pihkala \& Kai Hoffman \& Mauno Harmo. Helsinki: Ministry of Trade and Industry 1988, 22-24. 
ages were quite high, at 32 per cent in 1945, but the deliveries then came partly from the existing assets. In 1947 the figure was 15 per cent of industrial production, 11-12 per cent in 1948-49, 5-6 per cent in 1950-51, and 4 per cent in 1952.

The Finnish success in discharging its reparation obligations was aided both by good fortune (positive terms of trade, foreign credits, grants and gifts in kind and by the Soviet relaxation of some of the most stringent aspects of the Armistice agreement) and, as Charles Kindleberger put it, 'in major part to the intangible reality of a national effort of will, something that ordinary economic analysis is reluctant, and perhaps unable, to take into account'. ${ }^{15}$ The agency in charge of war reparation procurement (SOTEVA) was given dictatorial powers to obtain resources, but it had to use them only once. Industry willingly fulfilled the wellpaid orders.

\section{Finnish foreign trade and the balance of payments}

The Finnish food supply proved to be a most serious problem in the autumn 1944. In fact, the Swedish government created the very precondition for Finland's armistice, since food and other necessities which had earlier been imported from Germany were now allowed by the Allies to be purchased through Swedish channels. ${ }^{16}$ Sweden thus supplied in the winter of 1944-45 150,000 tons of cereals, 10,000 tons of sugar, margarine and salt, as well as coal and coke, which barely replaced the deliveries from Germany. In the spring of 1945, the Soviet Union also sold Finland 30,000 tons of cereals and 1,300 tons of sugar. In addition, some coal reserves had been accumulated in 1943. Mainly because of these deliveries the volume of imports between October 1944 and May 1945 was only a quarter of the level in the corresponding months in 1937-38, with exports at only 4 per cent of the previous level. Sweden accounted for three-quarters of these. It also sold some raw materials for war reparations on credit. ${ }^{17}$

The war reparations timetable and the actual list of goods were not in themselves a problem for the Finns. The main problem was to obtain foreign raw materials and machinery. Great Britain urgently needed timber and pulp, but not paper. It was thus ready to buy all the timber Finland was able to deliver. The British initially offered only pounds sterling while Finland wanted a barter trade, but after a Swedish intervention Great Britain agreed to sell Finland raw materials and to pay partly in dollars when the trade began in August 1945. ${ }^{18}$ Coal was not obtained from Great Britain, but Finland became an associate member of the European Coal Organization which distributed the scanty stocks of coal. Finland also became a member of other 'United Organizations of the Allied Powers' which allocated raw materials among the different nations.

Trade with the Soviet Union was strictly bilaterally balanced and Finland paid with wood and paper. Coal and coke were bought from Poland. The volume of foreign trade recovered quickly in 1946-48 and the expansion was aided by a

\footnotetext{
${ }^{15}$ Kindleberger, Suomen sotakorvaukset, 155.

${ }^{16}$ Nevakivi, Finnish Security Policy, 20.

${ }^{17}$ Pihkala, Kauppapolitiikka ja ulkomaankauppa, 29.

${ }^{18}$ Heikkilä, Liittoutuneet ja kysymys Suomen sotakorvauksista, 115-121, 151-153.
} 
Table 1 Foreign trade by volume, 1945-52 (1938=100)

\begin{tabular}{lrrrrrrrrr}
\hline & 1938 & 1945 & 1946 & 1947 & 1948 & 1949 & 1950 & 1951 & 1952 \\
\hline Exports, total & $100^{\mathrm{a}}$ & 17 & 47 & 66 & 72 & 87 & 100 & 126 & 111 \\
- Agriculture & 10 & - & - & - & - & 23 & 34 & 33 & 53 \\
- Raw wood & 9 & 8 & 37 & 61 & 67 & 79 & 144 & 205 & 186 \\
- Wood industry & 31 & 18 & 57 & 81 & 95 & 114 & 113 & 159 & 120 \\
- Paper industry & 42 & 17 & 50 & 64 & 72 & 77 & 89 & 103 & 84 \\
- Metal industry & 4 & 21 & 39 & 48 & 54 & 113 & 154 & 259 & 364 \\
Exports including war & & & & & & & & & \\
reparations & & 27 & 60 & 78 & 85 & 101 & 110 & 134 & 117 \\
& & & & & & & & & \\
Imports, total & 100 & 20 & 51 & 82 & 101 & 94 & 106 & 137 & 164 \\
- Raw materials & 53 & 27 & 56 & 94 & 107 & 102 & 113 & 147 & 160 \\
- Fuels & 10 & 8 & 51 & 62 & 115 & 96 & 143 & 170 & 184 \\
- For investment & 16 & 5 & 61 & 104 & 104 & 103 & 109 & 167 & 266 \\
- For consumption & 21 & 18 & 31 & 46 & 76 & 67 & 73 & 89 & 116 \\
Terms of trade & 100 & 92 & 106 & 124 & 122 & 111 & 100 & 136 & 131 \\
\hline
\end{tabular}

Note: ${ }^{a}$ Share in 1938, per cent including mining. In 1938 the trade was balanced.Source: Oksanen and Pihkala, Finland`s Foreign trade, 27, 122-123, 126-127.

marked improvement in the Finnish terms of trade. A new trade boom came in 1950-51 because of the Korean war, and the first commercial deliveries to the Soviet Union of Finnish metal industry products were made according to the 5 year trade agreement of 1950. (Table 1). The Soviet Union had secured for itself by the Paris Peace Treaty of 1947 a position of most favoured nation, which later caused problems in relation to GATT and EFTA. The Soviet Union's share was around 12 per cent of total exports or imports in 1949-50. Exports of paper were hampered by regulations on the use of paper in most Western European countries. ${ }^{19}$

The Finnish current account was at first kept in balance by a strict regulation of both exports and imports. War reparations were partly reflected in the foreign long-term indebtedness, whose increase had stopped by 1950 because of the export boom caused by the Korean war. (Table 2). The value of net transfers and gifts in kind (from Sweden, the United States, UNICEF, UNRRA, the International Red Cross etc.) in 1946 represented 15 per cent of the volume of the reparation deliveries. ${ }^{20}$ Import licenses were granted first of all to the war reparation industries and secondly to the export industries. The recovery of imports for consumption (Tables 1 and 5) thus lagged behind, although in 1948 more imports were allowed for political reasons. At first foreign trade was conducted on a barter basis,

19

Pihkala, Erkki, Sopeutuminen rauhaan (Adaptation to Peace), in Suomen taloushistoria (The Economic History of Finland) 2: Teollistuva Suomi, Eds. Jorma Ahvenainen \& Erkki Pihkala \& Viljo Rasila. Helsinki: Tammi 1982, 349.

20 Bärlund, Ragni, Finlands betalningsbalans under återbyggnadsperioden, Publikationer utgivna av Finlands banks institut för ekonomisk forskning, Serie A:12. Helsingfors 1951, 41. 
Table 2 Finland's balance of payments, 1945-52 (billion old FIM)a

\begin{tabular}{|c|c|c|c|c|c|c|c|c|}
\hline & 1945 & 1946 & 1947 & 1948 & 1949 & 1950 & 1951 & 1952 \\
\hline Exports (fob) ${ }^{b}$ & 52 & 231 & 452 & 565 & 656 & 815 & 1869 & 1568 \\
\hline Imports (cif) & -68 & -243 & -470 & -664 & -662 & -892 & $-1555-$ & -1822 \\
\hline Adjustments & -2 & -15 & 0 & -1 & -8 & 1 & -9 & -7 \\
\hline Trade balance & -18 & -27 & -18 & -100 & -31 & -76 & 305 & -261 \\
\hline Transport (net) & 6 & 18 & 27 & 45 & 64 & 64 & 115 & 104 \\
\hline Other services. (net) & 0 & 0 & 3 & -2 & 2 & -27 & -64 & -33 \\
\hline Interest (net) & -3 & -9 & -13 & -13 & -15 & -24 & -24 & -28 \\
\hline Transfers (net) & 4 & 18 & 14 & 14 & 9 & 5 & 5 & 5 \\
\hline Current account & -11 & 0 & 13 & -56 & 29 & -58 & 337 & -213 \\
\hline Long-term capital & 12 & 91 & 81 & 72 & 55 & -3 & -71 & -15 \\
\hline Short-term capital & 9 & -12 & 10 & -21 & 25 & 58 & -295 & 175 \\
\hline Errors, omissions & -10 & -76 & -78 & 5 & -109 & 3 & 1 & 53 \\
\hline Gifts in kind ${ }^{c}$ & 2 & 13 & 9 & 9 & 6 & 3 & 0 & 0 \\
\hline War reparations ${ }^{d}$ & -82 & -88 & -104 & -116 & -122 & -79 & -125 & -84 \\
\hline \multicolumn{9}{|l|}{ Assets/liabilities } \\
\hline - long term (net) & .. & .. & .. & .. & .. & -711 & -643 & -629 \\
\hline - short term (net) & .. & .. & .. & .. & .. & 39 & 314 & 126 \\
\hline
\end{tabular}

Notes: ${ }^{\text {a }}$ Since 1963 100oldFIM $=1$ newFIM

${ }^{\mathrm{b}}$ The export figures for 1947,1948 and 1949 include in newFmk 20,13 and 11 million compensation for the Finnish debts to Germany. The errors and omissions figures for 1945 and 1949 were affected by the devaluations of the FIM.

c The gifts received in kind and the war reparations are not included in the 'adjustments' item of the trade balance nor in the 'transfers' item of the service balance.

${ }^{d}$ In 1938 the short term assets almost balanced the long term liabilities.

Sources: For 1945-49, Bärlund, Finlands betalningsbalans under återbyggnadsperioden, and for 1950-52 Suomen maksutaseen kehityslinjat vuosina 1950-1974 (Finland's Balance of Payments in 1950-1974), Eds. Reino Airikkala \& Tuomas Sukselainen. Finlands Bank, Series A:41, Helsinki 1976, appendix 2.

but after 1946 it was mainly based on bilateral trade agreements and clearing accounts. $^{21}$

Finnish debts to Germany from 1941-44 were agreed to amount to almost 60 million new Finnish markkas (6000 million old markkas). They were mainly paid in 1947-50 by deliveries of wooden prefabricated houses and by a hydroelectric power plant constructed on a small area ceded (in the very north of the country) to the Soviet Union in 1947. Inflation had eroded the value of these debts since the original accounts were kept in Finnish markkas. In the meantime the Finns had had time to produce a revised version of the accounts.

The markka was devalued three times in 1945 due to inflation. The rate of exchange with the U. S. dollar thus appreciated from 49.35 (in 1933) to 136 old-FIM. The devaluations of July and September 1949 increased the rate to 231 old-FIM. The September devaluation was connected to the 44.4 per cent devaluation of the English pound and other Western European currencies. In 1948 Finland

21 Pihkala, Kauppapolitiikka ja ulkomaankauppa, 26. 
was able to join the IMF and World Bank (IBRD) and the par value of the markka was fixed in the summer of 1951. Finland's accession to the GATT agreement was signed in April 1950. In spite of this foreign trade remained strictly regulated until the end of the $1950 \mathrm{~s}^{22}$

\section{The settlement program and agriculture}

Before the war 55 per cent of the Finnish people were dependent on agriculture and forestry, mainly on family farms. In 1940 a settlement programme was approved to deal with the problem of the 422,000 evacuees from the areas ceded to the Soviet Union in March 1940, but the reconquest of Karelia in 1941 changed the situation. During the "Continuation war" land was also promised to soldiers. The contemporary spirit of agrarian democracy considered small land holdings to be the best means of solving not only the shortage of foodstuffs but also the settlement problems, as well as promoting employment and equalising the income and property distribution. A new law governing the acquisition of land for settlement purposes was quickly passed in April 1945, it being politically necessary to calm the minds not only of the evacuees, but also the frontier soldiers as well as the widows.

Over one-half of the arable land or tracts of forest needed for the new farms was taken from the lands owned by the state, local communities and parishes. The rest was private land and expropriated from companies and private foundations, from those not farming their land, and from the large farms, which were defined as farms in excess 15 hectares of fields or arable land and/or big forests according to a fixed scale. Areas populated by the Swedish-speaking minority ( 9 per cent of the total population) were, however, excluded from the programme for political reasons. Because of the marked inflation only 5 per cent of the 2.8 million hectares, which was redistributed to the 120,000 families who were settled, was freely sold. The fields and timberlands expropriated were compensated at the 'reasonable prices' of December 1944 and paid for in state bonds yielding 4 per cent annually and maturing in 1959. These securities were not inflation-indexed like the bonds used to compensate the property lost by the Karelian refugees. The payment of the loans granted by the state to the settlers was related to clearing and building activities on the new farms.

Most of the new holdings were either 'dwarf farms (0.5-2.0 hectares) or small holdings (2.1-5.0 hectares): by the 1950s the owners of these tracts were faced with poverty and urgent need to find employment in other occupations. The settlement programme had been mainly put into effect before 1948, but the stubborn and traditional belief in land reform, dating from after the Civil War of 1918, made Finland at the beginning of the 1950s the only (OEEC) country in which the number of farms was increasing. Nevertheless, it was notably the Agrarian Party which made the biggest advance in the 1948 parliamentary elections. Intimidation by using the idea or threat of kolkhozes was in that election a much used political tactic.

A production recovery to ease the strict rationing regime, particularly of foodstuffs, and an improvement in the standard of living were essential to maintain popular confidence in an economic system distorted by the needs of the war econ- 
Table 3 The volume of production in Finland and other indicators, $1945-52(1938=100)$

\begin{tabular}{lrrrrrrrr}
\hline & 1945 & 1946 & 1947 & 1948 & 1949 & 1950 & 1951 & 1952 \\
\hline Agriculture & 82 & 85 & 78 & 82 & 94 & 92 & 93 & 101 \\
Forestry & 122 & 111 & 108 & 90 & 76 & 83 & 101 & 100 \\
Industry & 89 & 104 & 114 & 130 & 135 & 143 & 163 & 159 \\
Construction & 70 & 80 & 90 & 115 & 135 & 141 & 142 & 151 \\
Transport, communications & 101 & 114 & 129 & 140 & 142 & 159 & 185 & 182 \\
Trade & 69 & 78 & 92 & 115 & 126 & 147 & 159 & 172 \\
Banks, insurance & 65 & 73 & 65 & 71 & 76 & 86 & 95 & 103 \\
Ownership of dwellings & 101 & 105 & 109 & 114 & 118 & 122 & 127 & 133 \\
Private services & 96 & 99 & 101 & 102 & 108 & 114 & 124 & 125 \\
Public services & 120 & 117 & 116 & 111 & 117 & 123 & 128 & 135 \\
GDP (factor prices) & 98 & 104 & 106 & 113 & 118 & 125 & 137 & 140 \\
Labour input, work years & 101 & 105 & 105 & 111 & 110 & 111 & 117 & 117 \\
Population, millions & 3,78 & 3,83 & 3,89 & 3,94 & 3,99 & 4,03 & 4,07 & 4,12 \\
\hline
\end{tabular}

Source: Hjerppe, Riitta, Finland's Historical National Accounts, 1860-1994: Calculation methods and statistical tables, Suomen historian julkaisuja 24. University of Jyväskylä, Department of History. Jyväskylä 1996, Tables 1 and 6.

omy. The settlement programme with its extensive land clearings to compensate for the lands lost in Karelia, some 12 per cent of the total farmed area, was reflected only slowly in the volume of agricultural production (Table 3). This was partly because of the weather conditions which were not as favourable as they had been at the end of the 1930s and partly because of the settlement programme itself which produced too small farms.

The high forestry production of 1945-46 (Table 3) resulted from the large cuttings of firewood undertaken both to employ the demobilized men after November 1944 and to help ease the acute shortage of fuel because of import-difficulties. The timber needed for the war reparation industries and for export, as well as for firewood, was expropriated from the forest owners at prices set by the government and which lagged behind inflation. Compulsory cutting was stopped by parliament at the end of 1947, and a fuel shortage was avoided by coal import. But in 1950-51 the Korean boom again boosted the cutting of timber. ${ }^{23}$

\section{Finnish industrial production, 1945-1952}

The volume of the Finnish Gross Domestic Product had already exceeded the prewar level by 1946, but the fruits of this recovery, especially in manufacturing, disappeared to the east in the form of war reparations. Accordingly, the prewar level of per capita GNP, was not reached until 1948 .

Because of the needs of the war reparations industries, production, especially

23

Pihkala, Sopeutuminen rauhaan, 342-346, 348 and Hietanen, Silvo, Silta yli kuilun (The bridge over the Chasm), in Kansakunta sodassa 3; Kuilun yli (A Nation in War, 3: Over the Chasm), Ed. Silvo Hietanen, Helsinki: Valtion painatuskeskus 1992, 309-11. 


\begin{tabular}{lrrrrrrrrr}
\hline Branch & Weight & 1945 & 1946 & 1947 & 1948 & 1949 & 1950 & 1951 & 1952 \\
\hline Foodstuffs & 143 & 82 & 97 & 106 & 123 & 139 & 157 & 168 & 177 \\
Textile, clothing & 143 & 77 & 90 & 95 & 105 & 112 & 123 & 131 & 134 \\
Woodworking & 94 & 91 & 104 & 112 & 118 & 118 & 122 & 142 & 120 \\
Paper industry & 148 & 53 & 74 & 85 & 93 & 85 & 101 & 118 & 103 \\
Printing & 65 & 156 & 111 & 114 & 156 & 160 & 176 & 186 & 189 \\
Leather, rubber & 23 & 68 & 87 & 114 & 134 & 140 & 161 & 171 & 160 \\
Chemical industry $_{\text {Non-mineral production }}$ & 18 & 146 & 174 & 205 & 219 & 227 & 278 & 308 & 316 \\
Metal, engineering & 54 & 73 & 85 & 105 & 130 & 142 & 157 & 164 & 149 \\
Other manufacturing & 205 & 105 & 133 & 148 & 178 & 184 & 168 & 210 & 209 \\
Electricity, hydro $^{11}$ & 98 & 111 & 117 & 134 & 123 & 137 & 153 & 150 \\
All industries & 76 & 101 & 102 & 103 & 112 & 130 & 149 & 165 & 172 \\
Employment $^{\text {a }}$ & 1000 & 89 & 104 & 114 & 130 & 136 & 143 & 163 & 159 \\
Productivity per worker & & 101 & 110 & 115 & 118 & 116 & 118 & 126 & 123 \\
\hline
\end{tabular}

Note: ${ }^{a}$ Including mining and quarrying

Source: Hjerppe, Reino and Hjerppe, Riitta et al., Suomen teollisuus ja teollinen käsityö 1900-1965 (Industry and industrial handicraft in Finland, 1900-1965), Kasvututkimuksia VII. Suomen Pankin Julkaisuja VII, Helsinki 1976, 122-28, 164-70.

for domestic consumption, suffered from a shortage of foreign currency for imported raw materials. While the export of the products of the Finnish paper industry was affected adversely by import controls in many countries until 1950.

The replacement of women in production by former soldiers was one cause of the lower productivity per worker in 1945. In 1948-50 the very slow increase in employment was more than matched by rising productivity. The loss of Karelia was significant for Finnish production. In 1938 Karelia had accounted for 10.7 per cent of the total industrial output, and in pulp production it had accounted for a quarter, as was the case too in the capacity of electric power output, which meant domestic electricity rationing continued until 1948. Harnessing the rapids of the Oulu-river began during the war, and after 1948 these power plants made it possible to discontinue the controls on the use of electricity. (see Table 4). The use of coal remained controlled until the 1950s. Metals and engineering, and to some extent the woodworking industries were stimulated by the war reparations deliveries. Armament factories were converted to the production of war reparation goods: machine gun factory turned to sewing machines and cannon factories to parts for locomotives and paper-making machinery. There was no need to build new factories to meet the war reparations.

The controls over the construction industry were intensified, since the shortage of coal and electricity had led to severe shortages of cement and nails. New hydroelectric plants and an improved national electric grid along with the needs of the war reparations industries were given priority. The rest was centrally distributed by licenses of the key building materials (nails and cement), for example to the settlers for construction of necessary buildings made mainly of wood. Build- 
ing designs were also standardised, and the prevailing circumstances created markets for wooden, hand-made or used nails and shingles and other substitutes. ${ }^{24}$

At the end of the war and after the delivery of vessels to the Soviet Union as war reparations, the Finnish maritime fleet had fallen to some 267,000 gross tons or less than 40 per cent of the prewar level. Moreover, most of the remaining vessels were leased in the summer 1945 to the Soviet Union until 1947. In fact, only 22 ships of some 65,000 gross tons remained in 1945 . These vessels had central orders to transport coal and other raw materials for the war reparation industries, and the route of every ship was to be reported to the Allied Control Commission. ${ }^{25}$ But, as far as sea-going steamers and motor ships were concerned, the Finnish merchant tonnage had regained its prewar level of some 600,000 tons by 1950 , thanks to the purchase of second-hand ships from abroad. A typical vessel was thus a 'Victorian' steamer while windjammers as well as small sailing coasters disappeared from the register around this time and the auxiliary tonnage started to decline. ${ }^{26}$ With the cutting off of the important Saima Canal by the boundary changes, previously significant inland water connections with the sea ceased.

At the end of 1944 the number of motor vehicles registered stood at 15,000, of which 4, 000 were cars. The pre-war level was reached by 1948, with imports consisting mainly of busses and lorries, the import of cars not being totally deregulated until 1963. A decline in railway traffic, especially passenger traffic, began at the end of the 1940s as a result of the increased resort to trucks and coaches. Deregulation was reflected as a slight decrease in the volume of communications. ${ }^{27}$

Only very modest increases of the allocated sales commissions were allowed in 1945-47, while the distribution of consumer goods based on 1938 sales was somewhat changed in favour of the co-operative wholesalers. The volume of sales, however, increased notably. (Table 3). The use of neon advertising signs was forbidden between 1941-49, but selling itself was not a problem, but rather the getting of goods for sale. The founding of new shops was allowed in 1948. In 1946 consumers had 53 different ration card forms because there were more items to be rationed than in the winter of 1944-45. The ration amounts increased and more and more goods became freely available. During 1949 regulations of the distribution system was mostly ended and in December that year the Ministry of Supply was closed, its remaining tasks being distributed among other ministries. After 1949 there was only one kind of ration card, and it itself became a matter of history in March 1954. Then a new phenomen appeared; the sales. ${ }^{28}$

Providing housing for the refugees from Karelia, the evacuees in Lapland, and for the returning soldiers was solved at first by the compulsory lodging of people at rents fixed by government. Since rent rises were hardly allowed, the rent index by 1949 was only two and a half times higher than it had been in 1938, while fuel prices and building costs were 11-12 times higher. The rents were thus often less than the landlord costs. The use of fuel, light and hot water was closely regu-

\footnotetext{
${ }^{24}$ Pihkala, Sopeutuminen rauhaan, 350 .

${ }^{25}$ Ibid., 352.

26 Kaukiainen, Yrjö, A History of Finnish Shipping. London and New York: Routledge 1993, 160-161.

${ }^{27}$ Pihkala, Sopeutuminen rauhaan, 352.

28 Salovaara, Karli, Sä̈̈nnöstellen selvittiin: Kansanhuoltoa 1939-1949 (Survive by Rationing: Supplying People, 1939-1949). Jyväskylä 1977, 140.
} 
lated in urban areas. Household appliances were virtually unknown except for radios. The shortage of dwellings was relieved gradually, especially in the countryside. Already by 1946 the number of dwellings completed annually had surpassed the prewar level, while other building was still one-third down. After 1947 the gap in the rents between old and new dwellings became a serious problem. In 1949 a state-subsidized dwelling production system (ARAVA) was created, and the rents payable for old houses were raised. Rent control was gradually abolished over the 1950 s. $^{29}$

Banks and insurance companies suffered markedly from the inflationary conditions because of the strict controls placed on interest levels. After 1935 the Bank of Finland's discount rate, to which the other interest rates were tied, had stayed at 4 per cent, but in June 1947 it was raised to $4^{1}$ /z per cent. In 1948 it rose further to over 7 per cent, but went down thereafter for political reasons. Bank lending was regulated according to the instructions of the Bank of Finland. ${ }^{30}$ Deposits were made tax exempt in 1946. At the end of 1945 the real value of the credit stock, including those of the Bank of Finland and the National Insurance Institution was 60 per cent of that in 1938, and in 1950 only 43 per cent. Credit markets were, however, becoming more normal in 1949 as the postwar inflation slowed.(Table 6). ${ }^{31}$

The provision of services recovered along with the growth of GDP. The total volume of public services was adversely influenced by the dismantling of the regulatory system, but this was compensated for the increases in education and social services provided by local communes reflecting the social legislation passed after 1947.(Table 3).

\section{The political economy of the postwar restoration}

Demands for food and other consumer goods in Finland grew impressively with the growing real earnings of wage-earners as compared with prewar levels. The dismantling of the 'hated' rationing system thus became an essential part of the 'incomes policies' pursued by the government. After the war the left wing parties wanted to turn the extensive wartime powers of economic regulation in the direction of a planned economy. And in October 1947 a plan aiming at controlling all kinds of economic activities by 'workers, consumers and small farmers' was actually promulgated. The right wing parties, however, advocated deregulation and a return to a 'free market' economy. This ideological division was further spiced by the political struggles over income distribution between wage workers and salaried people, between rural and urban groups and between those in agriculture and other occupations. Owing to the needs of the war reparations, the manufacturing sector was in a key position in such bargaining moves. The real solution to such disputes could only be met by increasing real supplies, that is by increasing production or by direct imports. But both strategies suffered from a shortage of foreign exchange to be earned by exports. Given these internal pressures and the

\footnotetext{
29 Pihkala, Sopeutuminen rauhaan, 351-352

30

Official Statistics of Finland 1954, 171

31 Pihkala, Sopeutuminen rauhaan, 356-357.
} 
Table 5 The recovery in Finnish private consumption, 1945-52 $(1938=100)$

\begin{tabular}{lrrrrrrrr}
\hline & 1945 & 1946 & 1947 & 1948 & 1949 & 1950 & 1951 & 1952 \\
\hline Durable goods & 50 & 53 & 56 & 72 & 72 & 92 & 125 & 161 \\
- purchases of vehicles & 10 & 13 & 16 & 43 & 97 & 134 & 269 & 411 \\
Semi-durable goods & 63 & 76 & 88 & 112 & 122 & 136 & 146 & 156 \\
Non-durable goods & 90 & 98 & 105 & 119 & 123 & 135 & 141 & 148 \\
Foodstuffs & 77 & 85 & 94 & 109 & 118 & 127 & 132 & 138 \\
- fats & 72 & 79 & 79 & 115 & 121 & 124 & 144 & 145 \\
- fruits, berries & 42 & 51 & 55 & 69 & 76 & 89 & 87 & 167 \\
- sugar, sweets & 22 & 34 & 68 & 140 & 172 & 191 & 168 & 164 \\
- coffee, tea, cocoa & 16 & 25 & 28 & 38 & 52 & 75 & 77 & 100 \\
Clothing & 62 & 76 & 88 & 114 & 128 & 143 & 152 & 159 \\
Health & 104 & 129 & 141 & 148 & 154 & 158 & 172 & 189 \\
Communications & 227 & 218 & 211 & 211 & 206 & 208 & 261 & 264 \\
Foreign travel & 6 & 9 & 16 & 23 & 53 & 78 & 154 & 127 \\
\hline
\end{tabular}

Source: Laurila, Eino H., Kulutus Suomen kansantaloudessa vuosina 1900-1975 (Consumption in Finnish economy in the years, 1900-1975), The Research Institute for the Finnish Economy B:42. Helsinki 1985, 465,467, 491,499,501, 511, 565,573,579,599,601,603,605.

external pressure, some socialist in character, time and the winning of a breathing space was essential to preserve the existing social system.

The recovery of consumption. The winter of 1944-45 was very difficult with respect to diet and general nutrition, clothing and other consumption (Table 5). ${ }^{32} \mathrm{At}$ first there was only enough foreign exchange to finance certain grain imports and other necessities like sugar, but by 1947 the situation was easing somewhat and imports of rice, coffee and citrus fruits could be afforded to some extent. By 1948 the total calorific intake per capita was being normalised through grain imports and the improved supply of dairy products, and there were even some exports of butter and meat. There was still, however, a shortage of luxuries, like coffee and tea, and foreign travel was strictly controlled (Table 5). Imported items were still subject to a license system.

Household disposable income was already higher in 1945 than during the war, and in 1948 exceeded the prewar level. Income differences were levelling off to some extent, and the pattern of consumption was different from that of 1938. Public consumption declined until 1947 with military demobilization.

The new income distribution. During the war the real incomes of the lower income groups had been maintained while higher income earners especially among the salaried, suffered rather. This accorded with the distribution principles of the rationing system. In 1944 consumer prices were twice and the wholesale prices 2.7 times higher than in 1938, but in 1943-44, inflation was still modest due to the heavy taxation. In 1945 inflation took off, since 'the demands of the people' had forced the government to double the minimum wages in the spring. Since

32 Pihkala, War Consumption and Financing, 114-117. 
Table 6 The use of resources and inflation, 1945-52 (1938=100)

\begin{tabular}{|c|c|c|c|c|c|c|c|c|}
\hline & 1945 & 1946 & 1947 & 1948 & 1949 & 1950 & 1951 & 1952 \\
\hline Private consumption & 88 & 95 & 104 & 112 & 122 & 133 & 143 & 152 \\
\hline Public consumption & 146 & 123 & 102 & 122 & 133 & 138 & 137 & 144 \\
\hline Investments & 65 & 92 & 109 & 122 & 134 & 140 & 157 & 181 \\
\hline Expenditure on GDP ${ }^{a}$ & 99 & 107 & 110 & 118 & 125 & 130 & 141 & 145 \\
\hline \multicolumn{9}{|l|}{ Disposable income of } \\
\hline households per capita & 81 & 93 & 98 & 104 & 111 & 120 & 131 & 137 \\
\hline Consumer prices & 285 & 454 & 588 & 792 & 806 & 919 & 1069 & 1113 \\
\hline Wholesale prices & 385 & 602 & 723 & 956 & 963 & 1121 & 1563 & 1577 \\
\hline \multicolumn{9}{|l|}{ Notes in circulation plus } \\
\hline public's deposits & 351 & 419 & 498 & 569 & 709 & 802 & 1082 & 1266 \\
\hline
\end{tabular}

Note: a The difference in the development of GNP at factor prices (Table 3) and that of expenditure on GDP $=$ GDP at market prices reflects the steep increase in indirect taxation as compared to 1938.

Sources: Hjerppe, Finland's Historical National Accounts, 106-107, 158-159 and Keto, Elokuvalippujen kysyntä, Tables 6.2. and 6.3.

the rise was 'solidaristic' or equal in markkas to all, industrial workers wages increased by 50-100 per cent. In October 1945 the consumer prices were 84 per cent higher than in May and 98 per cent higher if black market prices are taken into account. Over 1945 as a whole consumer prices rose 99 per cent or 121 per cent including black market prices. ${ }^{33}$ However, the rise allowed in rents was only 6 per cent. It was argued, later on, that the inflation was in part politically welcomed: it redistributed wealth and helped to liquidate the domestic state debt accumulated during the war by a 'heavy inflation tax' imposed on those who had had to buy or accept government bonds.

At the close of 1945 the Finnish banknotes in circulation were exchanged for a new issue, but half of the large nominal value notes were taken as a loan to the state to be repaid at the latest in 1949 with 2 per cent interest. This compulsory loan accounted for nearly half of the loans taken up by the government in 1946. This 'cutting of the bills' did not hamper the inflation, but it captured the hot money to the bank accounts which were traceable by the tax $\operatorname{man} .34$

The inflationary spiral. In the spring 1946 the inflationary policies were put on hold for a while and the wage increases allowed were only 8-15 per cent, to be followed by a total price and wage -freeze until the end of the year. The rise in

33 Jaakko Keto has tried in his Elokuvalippujen kysyntä ja siihen vaikuttaneet tekijät Suomessa 19151972 (with English summary: Demand for Cinema Tickets and Factors Affecting it in Finland, 19151972). Acta Academie Oeconomicae Helsingiensis, Series A:10. Helsinki 1974, appendix 3.3 to estimate the costs of living index including the black market prices as follows (compare table 6):

$1944 \quad 245 \quad 1948 \quad 898$

$1945 \quad 372 \quad 1949 \quad 898$

$\begin{array}{llll}1946 & 617 & 1950 & 1004\end{array}$

$1947 \quad 733$

34 See Pihkala, Sopeutuminen rauhaan, 357. 
Table 7 Earnings indices for some wage-earner groups in 1948 $(1938=100)$

\begin{tabular}{lrrrrr}
\hline & Agriculture & Industry & $\begin{array}{c}\text { Trade, } \\
\text { banks, etc. }\end{array}$ & $\begin{array}{r}\text { Public } \\
\text { services }\end{array}$ & $\begin{array}{r}\text { Other } \\
\text { services }\end{array}$ \\
\hline Nominal & 1390 & 1150 & 860 & 710 & 1060 \\
deflated by CPI & 204 & 168 & 126 & 104 & 155 \\
deflated by WPI & 145 & 120 & 90 & 74 & 111 \\
\hline
\end{tabular}

Notes: $\mathrm{CPI}=$ Cost of Living Index; $\mathrm{WPI}=$ Wholesale Price Index

Source: Pihkala, Sopeutuminen rauhaan, 357.

consumer prices over 1946 was thus only 16 per cent or 18 per cent if black market prices are included. 1947 began with a 5 per cent reduction in the prices of manufactured products and a 20-25 per cent reduction in the progressive income tax. Farmers' demands, their numbers now swelled by the new owners of holdings created under the settlement programme were partly met by dismantling meat rationing in the winter 1947. The price paid to the producer for milk was increased, and fertilizers prices reduced, which meant more subsidies. The increased use of grain in the production of meat meant that meat prices were suddenly 3-4 times higher. The badly lagging salaries of civil servants had to be increased in the winter of 1947 after the threat of a strike. All wage-earners in fact received a 'solidaristic' pay rise of 15 per cent on average in May 1947. Rents were also raised by 20-25 per cent. In autumn 1947 the Central Organization of Labour Unions threatened a general strike. Wages were consequently increased by 25 per cent on average, and prices were lowered by increased subsidies and a reduction in the turnover tax. A 5 per cent rise in consumer prices was to be compensated for by a 5.5 per cent rise in wages. A system of child allowances was created. Then the grain farmers in their turn threatened a strike. ${ }^{35}$

There was a subsequent threat by the Central Organization of Labour Unions to call a general strike to put pressure on the government. Governmental intervention to control wages and prices began to be reduced in 1948, but was not discontinued totally until the end of 1955 . $^{36}$

The Social Democrats were winning a ruthless struggle for the souls of the workers in trade union elections as well as in the parliamentary election in July 1948. External political pressures were also decreasing. Price control before these elections was so strict that factories were simply closed: as a consequence during the summer of 1948 20-30 per cent increases in prices were allowed. In July the procurement system for agricultural products was dissolved except for milk and grain. And by autumn 1948 about half of the most important foodstuffs had already been excluded from rationing. In 1948 as a whole the rise in consumer prices was however, only 11 (or 10) per cent because of increased imports of cheap food and reductions in indirect taxation.

\footnotetext{
35 Ibid., 338-341

36 Salovaara, Säännöstellen selvittiin, 177-178.
} 
Table 8 The structure of state expenditures in Finland 1938, 194551 (per cent/newFIM)

\begin{tabular}{lrrrrrrrr}
\hline & 1938 & 1945 & 1946 & 1947 & 1948 & 1949 & 1950 & 1951 \\
\hline Interest on debts & 5 & 5 & 5 & 5 & 3 & 4 & 4 & 3 \\
War reparations & - & 29 & 33 & 28 & 23 & 16 & 11 & 9 \\
Compensations due to the war & - & 8 & 16 & 17 & 16 & 15 & 14 & 13 \\
Defence & 30 & 19 & 8 & 6 & 5 & 5 & 5 & 5 \\
Subsidies, for settlement & 6 & 8 & 8 & 14 & 16 & 9 & 11 & 16 \\
Child and old age allowances & - & - & - & - & 3 & 12 & 12 & 14 \\
Education & 10 & 2 & 3 & 4 & 5 & 7 & 7 & 8 \\
Other expenditures & 49 & 29 & 27 & 26 & 29 & 32 & 36 & 32 \\
Total & 100 & 100 & 100 & 100 & 100 & 100 & 100 & 100 \\
Total, million new FIM & 37 & 364 & 490 & 589 & 777 & 891 & 999 & 1387 \\
Capital expenditure & & & & & & & & \\
$\quad$ million new FIM & 10 & 59 & 119 & 144 & 260 & 227 & 293 & 425 \\
\hline
\end{tabular}

Source: Valvanne, Statshushällningen åren 1938-1951, 6-7, 12-13.

The domestic postwar inflation virtually ended in 1949 as the prices of agricultural products turned down: the rise in consumer prices was only 3.5 per cent over the year or minus one per cent including black market prices. On the other hand, the heavy devaluations of the markka raised import prices, thus triggering a new wages-price spiral in 1950, reinforced too by the boom caused by the Korean war. ${ }^{37}$

\section{The Finnish State Finances}

The costs of war reparations and other legacies of the war, like the settlement and reconstruction programmes, including loans to the resettled and general wartime compensations are clearly reflected in the contemporary state expenditures. ${ }^{38}$ After 1948 such financial burdens lessened, but there began the first indications of expanding expenditures on the emerging welfare state and on other social objectives like improving the badly rundown public infrastructure. (Table 8)

Legislation gave the municipal administrations new social responsibilities after 1946 which were financed mainly by increased taxation and not by running public deficits. Real state expenditures were thus by 1948 over twice and by 1952 three times higher than they had been in $1945 .{ }^{39}$ The rate of municipal taxation increased from 7 to 9 per cent of total income in 1945 to $9-12$ per cent of total

37 Pihkala, Sopeutuminen rauhaan, 358-359; and Keto, Elokuvalippujen kysyntä, Table 3.3.

38 The analysis is based on Valvanne, Heikki, Statshushdllningen dren 1938-1951, Publicationer utgivna av Finlands banks institut för ekonomisk forskning, Series A:13. Helsingfors 1952

Economic History of Finland 3: Historical statistics, Ed. Kaarina Vattula. Helsinki: Tammi 1983, $360,362,364-367$. 
Table 9 The structure of the Finnish state revenue in 1938 and 1945-52 (per cent/million new FIM)

\begin{tabular}{lrrrrrrrr}
\hline & 1938 & 1945 & 1946 & 1947 & 1948 & 1949 & 1950 & 1951 \\
\hline Income \& wealth taxes & 18 & 25 & 24 & 25 & 23 & 17 & 24 & 21 \\
Additional wealth taxes & - & 13 & 14 & 7 & 6 & 6 & 3 & 0 \\
Sales taxes & - & 15 & 21 & 25 & 26 & 29 & 27 & 32 \\
Alcohol monopoly & 7 & 21 & 17 & 17 & 13 & 9 & 9 & 8 \\
Customs duties & 38 & 1 & 4 & 7 & 9 & 11 & 10 & 9 \\
Excise duties (coffee, tea etc) & 10 & 7 & 8 & 7 & 10 & 10 & 9 & 8 \\
Payments for children and the old & & & & & & & & \\
$\quad$ retirement allowances & & - & - & - & - & 1 & 8 & 8 \\
Stamp duties, fines etc. & 6 & 6 & 3 & 4 & 4 & 6 & 4 & 8 \\
Other income & 21 & 12 & 8 & 8 & 8 & 4 & 5 & 6 \\
Total, per cent & 100 & 100 & 100 & 100 & 100 & 100 & 100 & 100 \\
Total, new FIM & 49 & 346 & 577 & 675 & 983 & 1058 & 1314 & 1905 \\
Capital income, new FIM & 2 & 5 & 6 & 16 & 7 & 32 & 40 & 18 \\
State taxes/GDP, per cent & 9.9 & 20.2 & 24.1 & 20.7 & 21.6 & 20.5 & 21.1 & 19.1 \\
\hline
\end{tabular}

Source: Valvanne, Statshushållningen åren 1938-1951, 6-7, 18-19 and calculations made by the author.

income in $1950 .^{40}$ The work of private relief organizations like the 'Kansanapu' (People's Aid) were eventually taken over by the improved social security system. The contributions made by UNICEF, UNRRA and other international relief organizations should also be borne in mind. (See Table 2).

Before the war most of the capital expenditures of the state were real investments in state enterprises or in buildings, roads and bridges and in machinery. In the post-war period over one third of the capital expenditures were loans, at first to the settlers and after 1949 also to the state-supported housing corporations. In 1949-51 this item also included construction works to provide work for the unemployed.

Total tax revenues were kept high by the progressive income tax and especially, from 1945, by an extra wealth tax, a so-called expropriation tax: inflation boosted the burden of these taxes. ${ }^{41}$ The yield of the sales tax and other indirect taxes like customs duties and the excise taxes on 'stimulants' such as tobacco and coffee increased, with the growing sales volume and imports. The revenue from the State Alcohol Monopoly was, in contrast, clearly decreasing. (Table 9).

The relatively modest budget deficits were thus financed by net borrowing, and the cash deficits were no longer a problem. (Table 10).

Domestic debt and the cash debt owed to the Bank of Finland were both in decline by 1946, not only in real terms but also absolutely: however, they were more than replaced by increasing foreign indebtedness. Foreign debt, like the index-tied Special Liabilities on compensations arising from the war, were not to be

\footnotetext{
${ }^{40}$ Official statistics in Finland 1950, 246.

${ }^{41}$ Pihkala, War Consumption, 121.
} 
Table 10 The financing of the post-war budgets in Finland, 1945-51 (million new FIM)

\begin{tabular}{lrrrrrrr}
\hline & 1945 & 1946 & 1947 & 1948 & 1949 & 1950 & 1951 \\
\hline Income & 351 & 584 & 692 & 990 & 1090 & 1354 & 1923 \\
Expenditure & 423 & 609 & 733 & 1037 & 1117 & 1291 & 1812 \\
Surplus/deficit & -72 & -25 & -41 & -47 & -27 & 63 & 111 \\
Net borrowing & 38 & 68 & 27 & 38 & -33 & -10 & 18 \\
Cash surplus/deficit & -33 & 43 & -15 & -9 & -60 & 52 & 128 \\
\hline
\end{tabular}

Sources: Tables 7 and 8 and Valvanne, Statshushállningen áren 1938-1951, 9.

Table 11 Government debt in Finland, 1945-51 (million new FIM at year end)

\begin{tabular}{lrrrrrrr}
\hline & 1945 & 1946 & 1947 & 1948 & 1949 & 1950 & 1951 \\
\hline Foreign debt & 229 & 335 & 381 & 440 & 632 & 658 & 661 \\
Domestic debt & 382 & 379 & 361 & 337 & 305 & 291 & 305 \\
Cash debt & 209 & 166 & 181 & 190 & 249 & 197 & 69 \\
Total & 819 & 880 & 922 & 967 & 1186 & 1146 & 1035 \\
Special Liabilities & 63 & 260 & 493 & 498 & 441 & 483 & 526 \\
Debt/GDP, per cent & 61 & 52 & 48 & 36 & 37 & 30 & 20 \\
\hline
\end{tabular}

Sources: Valvanne, Statshushällningen áren 1938-1951, 24 and calculations made by the author. The devaluations of the FIM in 1949 is reflected in the foreign debt.

liquidated by inflation. The international level of inflation was at that time much higher than the interest on foreign loans. However, the debt ratio to the GNP was clearly declining. (Table 11).

As far as the government finances were concerned the worst was over by 1948, and after 1951 they can be considered normal. In 1952 Finland was enjoying the fruits of the Korean war boom, the last war reparations deliveries took place in September, Helsinki had the Olympic Games, and a Finnish maiden won the Miss Universe contest. The people felt that the nightmares of the 1940s were over.

In 1955 Finland was able to join the Nordic Council, and the United Nations and the Soviets relinquished control of the Porkkala base to Finnish forces. Foreign trade was liberalized in 1958-59. Finland opened her way to further European integration by concluding in 1961 an agreement of association with European Free Trade Association (EFTA).

\section{Conclusions}

The recovery of the Finnish post-war economy gained indirectly from the general economic recovery of Western Europe, although Finland was not able to partici- 
pate in the Marshall Aid programme. Thanks to the expansion in exports to the west and some valuable foreign loans, Finland was able to finance its war reparations and carry through its immediate domestic postwar tasks, the resettlement of people and reconstruction, without hyperinflation. Inflation was mainly caused by the need to raise wages and to end the rationing system for political reasons, reasons accentuated by the postwar political situation with its strong popular support for socialist or communist ideas. Similar domestic political situations were at that time prevailing in France and Italy and to a lesser extent in Great Britain. Finland, however, bordered the Soviet Union and was bound to that state by the war reparations and the other peace terms of a lost war. Finland was, however, able to find solutions of its own in these awkward political and economic situations, external and internal, and was able to slide little by little into the ambit of western economic co-operation. In this context the Finnish upper and middle classes were ready and willing to pay the bill but not to accept fundamental change in the prevailing economic system between 1945 and 1952. The contribution of the Finnish Social Democrats, in contrast to the Communists, was also very notable, especially in the struggle for leadership in the trade unions.

This paper reminds us of the significance of political circumstances for the room for manoeuvre in economic policy-making, a fact that is easily forgotten or underestimated by economists. When considered in the light of the pathdependency theory developed by Douglas C. North, the Finnish economic regime did not in 1945-47 differ so remarkably in its content from that in a number of other West European countries, although the character of single measures may well have varied. ${ }^{42}$ But while the Marshall Plan and the OEEC and the coming of Nato in 1949, made for decisive change in the economic regimes of Western Europe (especially in West Germany), Finland was bound to continue on the path established in 1945-48 because of her dependence on the Soviet Union, militarily, politically, economically and partly ideologically and so stay outside the new paths being pursued in Western Europe. Finland thus remained, in terms of economic system and co-operation 'in between', since in Eastern Europe the new path was one of socialism.

\footnotetext{
42 See Europe's Post-war Recovery, Ed. Barry Eichengreen. Cambridge: Cambridge UP 1995, and The Reconstruction of the International Economy, 1945-1960, Ed. Barry Eichengreen. Cheltenham: Edward Elgar 1996. It is interesting that in Belgium in 1944-45 that the social causes for the increases in nominal wages and the labour market measures were analogous to those in Finland. See Isabelle Cassier, Belgian miracle to slow growth, in Europe's Post-war Recovery, Ed. Barry Eichengreen. Cambridge: Cambridge UP 1995, 274-275. Certain articles in Postwar Economic Reconstruction and Lessons for the East Today, Eds. Rudiger Dornbusch \& Wilhelm N611ing \& Richard Layard. Cambridge, Mass.: MIT Press 1993, contain information on measures in 1945-47 in Germany, Italy, France, the United Kingdom and in Japan before the Dodge plan of 1949. A thorough comparative study, however, is still lacking. In 1947, for example, the reactions of the Communists were similar in France and in Finland. A comparison of the European monetary policies, however, pursued is discussed in John G. Gurley, Excess liquidity and European monetary reforms, 19441952, in The Reconstruction of the International Economy, 1945-1960, Ed. Barry Eichengreen. Cheltenham: Edvard Elgar 1996, 295-318, first published in American Economic Review, vol. XLIII, March 1953:1.
} 